\title{
Chromobox Protein Homolog 5
}

National Cancer Institute

\section{Source}

National Cancer Institute. Chromobox Protein Homolog 5. NCI Thesaurus. Code C73685.

Chromobox protein homolog 5 (191 aa, $\sim 22 \mathrm{kDa}$ ) is encoded by the human CBX5 gene.

This soluble, nuclear protein plays a role in epigenetic modification of chromatin, by catalyzing the monomethylation of lysine 5 of histone $\mathrm{H} 2 \mathrm{~B}$. The outcome of this modification is associated with either activated gene transcription, or, if further processed to trimethylated lysine 5, epigenetically repressed gene transcription. By affecting the balance of chromatin in heterochromatin and euchromatin at specific gene loci, this protein acts as a candidate tumor suppressor. 